( К. О. Чепурна, к.т.н., доцент, О. С. Оліяненко, магістр, КП। ім. Ігоря Сікорського, Київ, Україна

\title{
ДОСЛІДЖЕННЯ АДГЕЗІЇ ПОЛІПРОПІЛЕНОВИХ ПЛІВОК ДО ПОВЕРХНІ ВІДБИТКІВ ЕЛЕКТРОГРАФІЧНОГО ДРУКУ В ПРОЦЕСІ ЛАМІНУВАННЯ
}

\section{Досліджено вплив технологічних параметрів процесу ламінування на адгезію плівок до поверхні відбитків електрографічного друку.}

Ключові слова: ламінування; адгезія; електрографічний друк; температура та швидкість ламінування; відсоток накладання фарб; адгезійна міцність.

\section{Постановка проблеми}

Для оздоблення відбитків досить широко застосовується процес ламінації, що надає відбитку більшої насиченості, контрасту або певної текстури, а також дозволяє захистити друковану продукцію від зовнішніх негативних впливів: вологи, пилу, механічних пошкоджень тощо $[1,2]$. Широкої популярності набирає використання 3D-плівки для ламінування, яка створює ілюзію тривимірного зображення і відчуття об'ємності завдяки особливому розташуванню елементів і візерунків на плівці, що заломлюють промені світла [3].

Якість ламінування та готової продукції істотно залежать від природи, гладкості та мікроструктури поверхні паперу та фарбового шару. Взаємодія клеючих складових полімерних плівок із папером відбувається на поверхні волокон, тому при зменшенні пористості реальна площа контактної взаємодії полімеру з основою відбитка зменшується, що стає причиною відшаровування плівки. Від якості ламінування залежать естетичні та експлуатаційні характеристики продукції, тому дослідження адгезії плівок до поверхні паперу та задрукованих відбитків для визначення оптимальних технологічних параметрів процесу ламінування $\epsilon$ актуальною практичною задачею.

\section{Аналіз попередніх досліджень}

Оздобленню ламінуванням підлягають зображення, надруковані різними способами друку. Відповідно до фізико-хімічних властивостей матеріалів, які піддаються ламінуванню, обирають оптимальний спосіб та технологічні режими ламінування. Найбільш проблемними основами для гарячого ламінування є відбитки струминного друку та фотографії. Основними дефектами на зазначених поверхнях є: поява бульбашок та зморшок на поверхні, відшаровування

\footnotetext{
(c) $2016 \mathrm{p}$.
} 
плівки, зміна кольору відбитка. Як правило, причинами виникнення дефектів $€$, по-перше, несумісність матеріалів, тобто будь-якої складової барвників/ пігментів фарбового шару та клейового шару плівки; по-друге, наявність у матеріалах складових, чутливих до дії температур понад $100^{\circ} \mathrm{C}$ (наприклад, желатинове покриття фотопаперу), а також некоректний вибір технологічних режимів ламінування $[4,5]$.

Для контролю якості ламінування використовують такі показники як міцність припресування до основи, відсутність скручування, прозорість плівки, збереження колірних характеристик, відсутність наявних візуальних дефектів.

Адгезію плівок до відбитків оцінюють, визначаючи зусилля необхідне на відшарування плівки від основи або від шару фарби. Найвища міцність спостерігається, коли відшарування плівки йде по основі. Скручування оцінюють величиною підняття країв стосовно горизонтальної поверхні. Ця величина не повинна перевищувати $5 \%$. Зовнішній вигляд, відсутність дефектів, відповідність кольорової гами оцінюються візуально шляхом порівняння з затвердженим еталоном. На відбитках не повинно бути зморшок, вдавлювань, блискіток і смуг. Плівка на відбитках повинна бути прозорою і безбарвною, колірна гамма залишатися без змін [1-6].

Адгезія залежить від природи і властивостей контактуючих поверхонь і площі контакту. На величину площі контакту впливають такі фактори як змочування, здатність адгезиву заповнювати нерівності твердої поверхні основи, витісняючи при цьому повітря. Численні бульбашки повітря, що перебувають у порах поверхні основи, перешкоджають досягненню максимально можливого контакту. Таким чином, шорсткість поверхні основи і чистота $€$ важливими факторами, що впливають на щільність і площу контакту, а в кінцевому підсумку - на адгезію [7].

Значна частка поліграфічної продукції виготовляється цифровим друком і тому існує проблема ламінування цифрових відбитків як одразу після друку, так і через певний проміжок часу, а також проблеми ламінування темних суцільних заливок (плашок). Залежно від виду цифрової друкарської машини, віддруковані аркуші покриваються ф'юзерним маслом, воском, парафіном, що негативно впливає на адгезію плівки. Плівка відшаровується суцільно від поверхні відбитка або з поверхневим шаром фарби одразу або за деякий час на післядрукарських операціях (бігування, фальцювання, перфорація). Причиною низької адгезії плівки до поверхні відбитків, надрукованих цифровими друкарськими машинами, $\epsilon$ те, що клей (адгезив) затримується тонером (фарбою) на поверхні відбитка, не проникаючи вглиб основи [8].

\section{Мета роботи}

Метою даної роботи було дослідження адгезії плівок до поверхні відбитків електрографічного друку для встановлення оптимальних технологічних параметрів процесу ламінування. 


\section{Результати проведених досліджень}

Якість ламінованої продукції залежить від багатьох факторів: правильного вибору та налаштування технологічних режимів процесу ламінування, вибору матеріалів (типу, товщини та складу плівки, складу та фактури паперу, складу та в'язкості клею, складу фарб), їх вхідного контролю та сумісності, способу ламінування, типу ламінатора, кваліфікації робітників, досвіду їх роботи. За результатами проведеного аналізу впливу того чи іншого фактору на якість процесу ламінування розроблено діаграму Ісікави, яка включає ступінь вагомості кожного фактору, що наведено на рис. $1[9,10]$.

Найбільший вплив на якість ламінування мають фізико-хімічні та структурно-механічні властивості матеріалів - паперу, плівки, фарб (які закладаються виробниками), їх взаємна адгезія, а також технологічні режими процесу ламінування: температура, величина тиску і швидкість ламінування.

До паперу висувають наступні вимоги: він повинен добре сприймати друкарську фарбу, мати рівну поверхню, бути однорідним, мати однотонний колір, достатню механічну міцність, легко деформуватися під тиском без помітних залишкових деформацій, бути хімічно інертним, мати чисту поверхню з мінімальною засміченістю, бути без складок та інших дефектів.

Неоднорідність структури паперу та переважна орієнтація волокон у напрямку відливу обумовлюють неоднорідність механічних властивостей аркуша паперу в різних напрямках. Розкрій паперу повинен бути таким, щоб у процесі припресування поздовжній напрямок плівки збігався 3 поздовжнім напрямком паперу.

До відбитків висувають такі вимоги: якість друку на аркушах повинна задовольняти технічним вимогам на друк, фарба на відбитках повинна бути повністю закріплена і не відмарюватися. Поверхня відбитків повинна бути чистою, без пилу і противідмарювальних засобів. Друк з обох сторін не рекомендується.

Крім того, на міцність припресування істотно впливає товщина фарбового шару і насиченість відбитка. Значна товщина фарбового шару погіршує дифузію клейового шару плівки в поверхню задрукованого матеріалу, знижує щільність ламінування, міцність закріплення полімерної плівки на відбитку, призводить до видимих дефектів. Як правило, такі відбитки вимагають підвищення температури і тиску, щоб забезпечити достатню щільність і міцність ламінування [6]. Багатофарбові відбитки повинні мати фарбові шари мінімальної товщини. Рекомендовано застосовувати друкарські фарби, стійкі до підвищених температур, спиртів. Усі відбитки одного накладу повинні мати однаковий розмір (допуск \pm 2 мм). Краї аркушів не повинні мати заломів та надривів [1, 2].

Технологічні режими процесу ламінування в основному залежать від властивостей матеріалів - плівок та клеїв, конструкції обладнання та способу ламінування. Температура, тиск, швидкість $€$ контрольованими факторами 

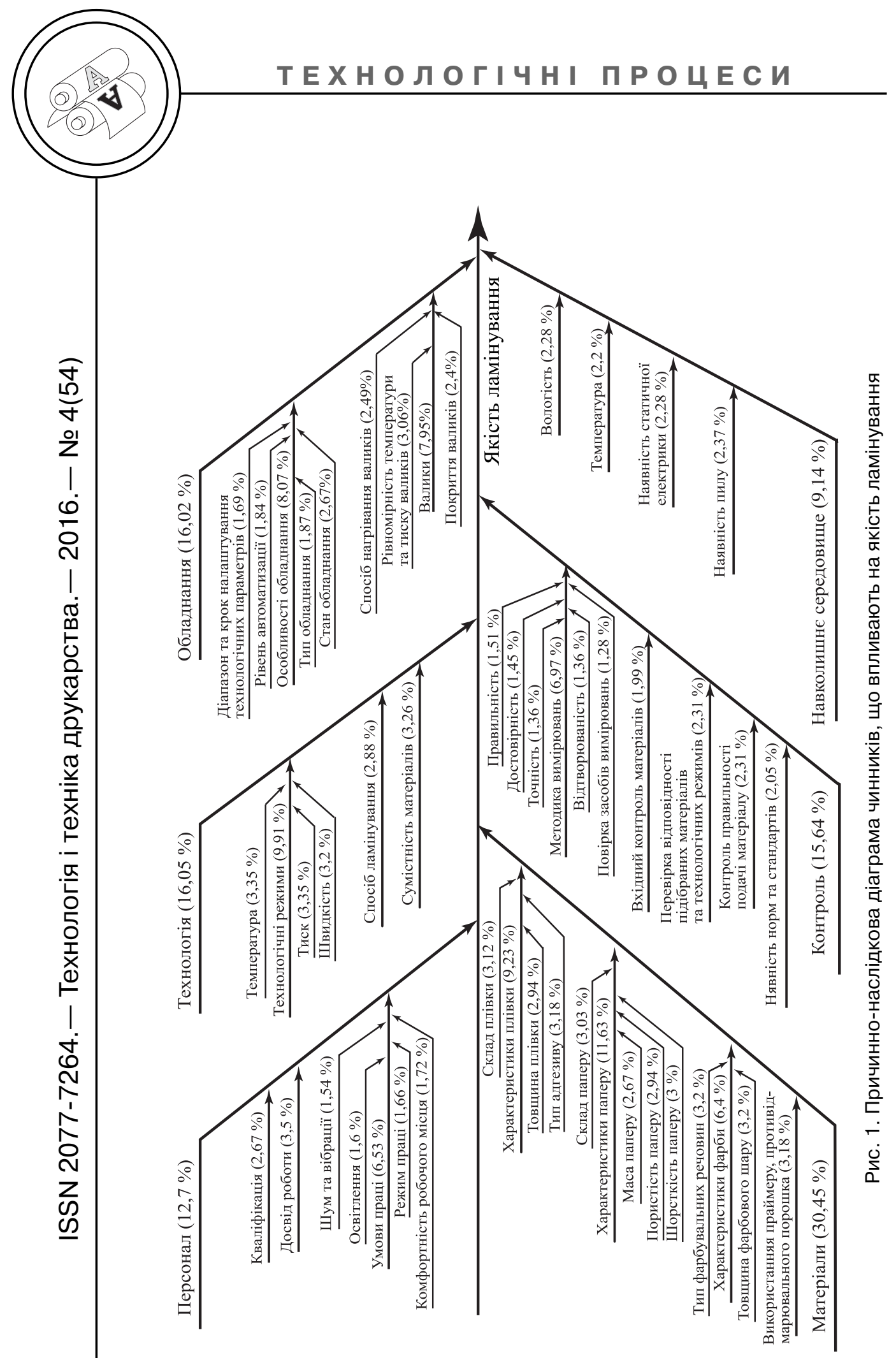
і можуть бути змінені в процесі ламінування для підвищення якості продукції.

Тиск забезпечує контакт поверхонь, вдавлювання адгезиву в пори паперу, згладжування макронерівностей паперу. Тиск залежить від технологічних факторів - гладкості та щільності паперу, в'язкості адгезиву.

Температура забезпечує плавлення адгезійного шару для зчеплення з основою, встановлюється відповідно до температури плавлення адгезиву, а їі підвищення сприяє збільшенню міцності ламінату та гладкості поверхні.

Швидкість визначає час знаходження плівки та основи в зоні контакту при заданих температурі та тиску. Збільшення або зменшення швидкості ламінування від технологічно необхідної може викликати різні дефекти.

Як результат проведеного аналізу ламінованої продукції, встановлено основні типові дефекти, які виникають в процесі ламінування, та визначено методи їх попередження, що наведено на рисунку 2 [10-13].

Для дослідження адгезії було розроблено тест-форму, яка містить плашки з накладанням фарб y $300 \%, 200 \%, 100 \%, 50 \%, 0 \%$.
Дослідження проводили на папері, придатному для цифрового друку, який застосовуються при виготовленні обкладинок та палітурок, характеристики наведені в таблиці.

Ламінування зразків здійснювали на рулонному ламінаторі Royal Sovereign RSH 380SL, який працює як за гарячою так і за холодною технологією, температура ламінування 20-150 С, товщина плівок 25-250 мкм. Для ламінації було обрано матову та глянцеву біаксіально орієнтовані поліпропіленові плівки виробника pkcco (Корея), товщиною 27 та 24 мкм відповідно.

Попередньо проведені дослідження дозволили визначити такі найбільш оптимальні режими ламінування:

1. температура ламінування $110^{\circ} \mathrm{C}$; швидкість 2 м/хв.;

2. температура ламінування $110^{\circ} \mathrm{C}$; швидкість 5 м/хв.;

3. температура ламінування $135^{\circ} \mathrm{C}$; швидкість 2 м/хв.;

4. температура ламінування $135^{\circ} \mathrm{C}$; швидкість 5 м/хв.

При визначенні температури ламінування треба враховувати характеристики контактуючих поверхонь. Швидкість ламінування залежить від температури

Характеристики паперів

\begin{tabular}{|c|c|c|c|}
\hline Характеристики & DNS Color Print & SCP & Prima Silk \\
\hline Виробник & Mondi (Австрія) & Mondi (Словакія) & Sаррі (Австрія) \\
\hline Маса 1 м², г & 100 & 120 & 250 \\
\hline Пухкість, см³/г & 0,81 & 0,77 & 0,92 \\
\hline Непрозорість, \% & 91 & 91 & 98,5 \\
\hline Білизна СІЕ, \% & 122 & 145 & 127 \\
\hline
\end{tabular}




\section{ТЕХНОЛОГ І Ч Н І П РО ЦЕ С И}

Дефекти

Можливі причини

Методи запобігання

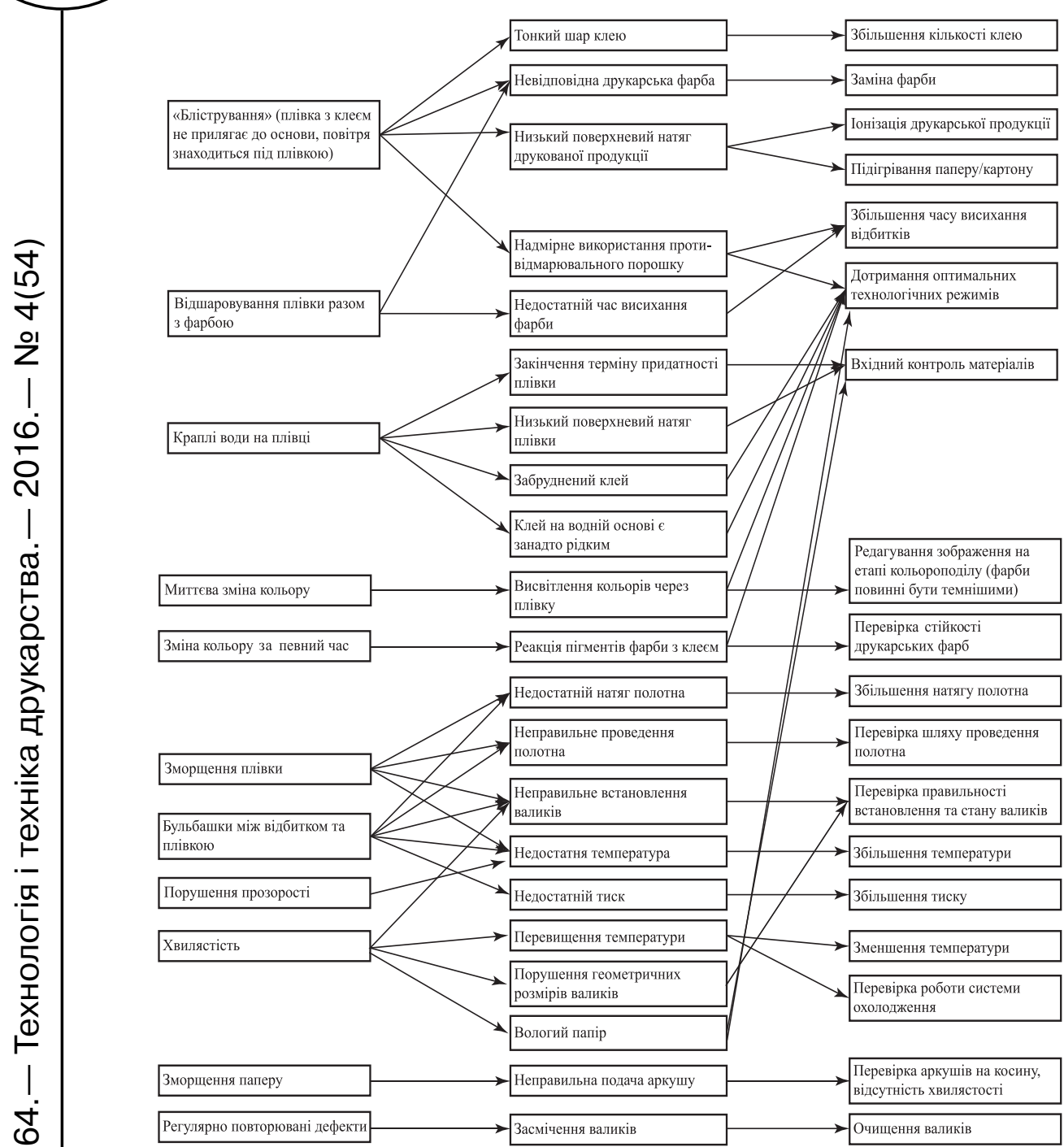

Рис. 2. Дефекти при ламінуванні

нагрівального валу і визначає тривалість взаємодії контактуючих поверхонь при певній температурі та тиску. У випадку, коли ламінатор працюватиме занадто швидко, плівка не триматиметься на матеріалі. Оптимальний баланс температурашвидкість-тиск відрізняється для різних паперів і плівок [14].
Для визначення ступеню адгезії за основу взято метод решітчастих надрізів (DIN EN ISO 2409-2013) [15]. Дослідження проводили на ламінованих тестових відбитках, отриманих за відповідних технологічних режимів ламінування, а саме на тестових полях виконували шість паралельних надрізів до поверхні паперу довжиною 

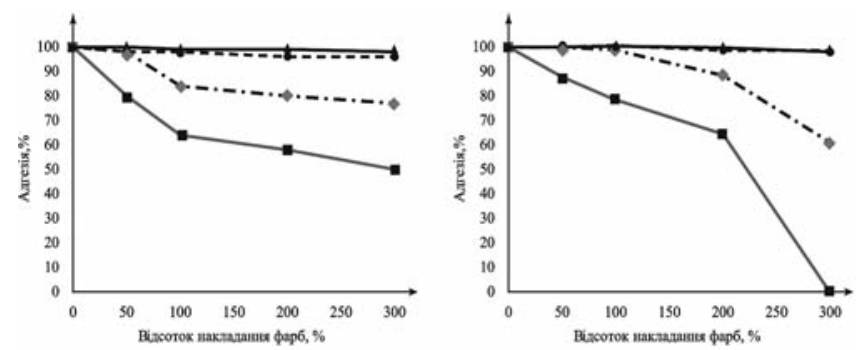

-๑ - температура $110^{\circ} \mathrm{C}$

-4- пвилкість $2 \mathrm{M} / \mathrm{xB}$

- температура $110^{\circ} \mathrm{C}$

швидкість $5 \mathrm{M} / \mathrm{xB}$

$\downarrow$ температура $135^{\circ} \mathrm{C}$

температура $135^{\circ} \mathrm{C}$

•- Температура $135^{\circ} \mathrm{C}$

Рис. 3. Графік залежності адгезійної міцності від відсотка накладання фарб при ламінуванні глянцевою (1) та матовою (2) плівками, папір DNS Color Print, 100 г/м²

20 мм на відстані одного міліметра один від одного, аналогічним чином наносили надрізи в перпендикулярному напрямку. Як результат, на поверхні утворюється решітка з надрізів, яка містить 25 квадратів розміром $1 \times 1$ мм. Надрізи наносили на ріжучому плотері. Адгезію оцінювали за площею плівки, яка не відшарувалася від поверхні відбитка у відсотках. Для підвищення точності вимірювань, надрізи виконували у декількох місцях тестових полів, з отриманих значень визначали середнє.

Результати досліджень адгезійної міцності при ламінуванні глянцевою та матовою плівкою для трьох паперів представлено на рис. 3-5.

На основі отриманих даних (рис. 3-5) можна зробити висновок, що максимальний ступінь адгезії досягається при мінімальній кількості фарби на відбитку, а у випадку необхідності отримання значного фарбового шару, операцію ламінування слід проводити за максимально рекомендованої температури $\left(135^{\circ} \mathrm{C}\right)$ і при мінімальній швидкості (2 м/с). Підвищення температури інтенсифікує процес дифузії адгезиву в пори субстрату, а мінімальна швидкість забезпечує більш довготривалу взаємодію поверхонь у зоні контакту.
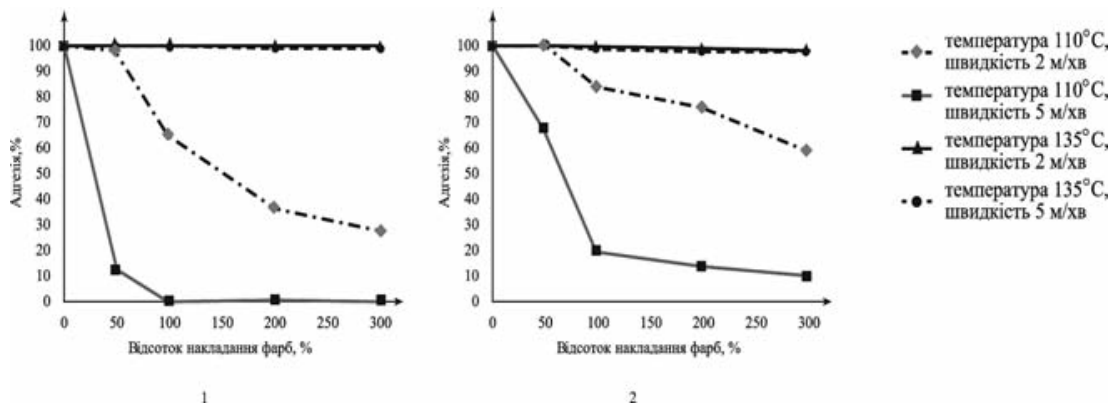

Рис. 4. Графік залежності адгезійної міцності від відсотка накладання фарб при ламінуванні глянцевою (1) та матовою (2) плівками для паперy Mondi SCP, 120 г/M² 

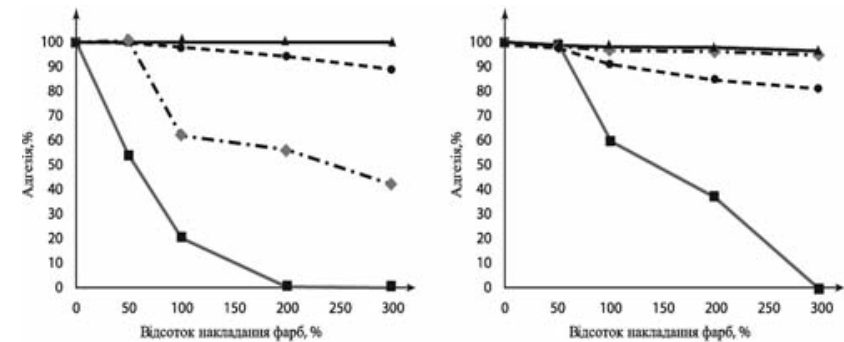

-\$ температура $110^{\circ} \mathrm{C}$

швидкість $2 \mathrm{M} / \mathrm{xв}$

- температура $110^{\circ}$

температура $135^{\circ} \mathrm{C}$

- температура 135

-. Tesmeparypa $135^{\circ} \mathrm{C}$

Рис. 5. Графік залежності адгезійної міцності від відсотка накладання фарб при ламінуванні глянцевою (1) та матовою (2) плівками для паперу Sappi Prima Silk, 250 г/м²

Пористість субстрату та форма пор також впливають на адгезію. Тому рекомендовано уникати суцільного задруковування поверхні субстрату, оскільки фарба (пігмент/тонер) закриває пори матеріалу, що призводить до зниження адгезії плівкових матеріалів до поверхні відбитків.

\section{Висновки}

Для дослідження адгезії плівки до відбитків електрографічного друку обрано параметри, зміна яких суттєво впливає на якість поліграфічної продукції: температура та швидкість ламінування, відсоток накладання фарб.

За результатами проведених досліджень можна зробити висновок, що найбільший вплив на адгезію, тобто міцність зчеплення плівки з поверхнею відбитка, чинить температура та швидкість ламінування (яка визначає тривалість контакту поверхонь при температурі), відсоток накладання фарб та їх парна взаємодія.

\section{Список використаної літератури}

1. Бобров В. И. Технология и оборудование отделочных процессов : Учебное пособие / В. И. Бобров, Л. Ю. Сенаторов. - Москва : МГУП, 2008. $434 \mathrm{c}$.

2. Гавенко С. Ф. Оздоблення друкованої продукції : технологія, устаткування, матеріали : Навч. посіб. для студ. вищ. навч. закл. / С. Ф. Гавенко, Е. Т. Лазаренко, Б. Г. Мамут, М. В. Самбульський, Я. Циманек, С. Якуцевич, С. М. Ярема. - К. : УН-т «Україна»; Л. : Укр акад. друкарства, 2003. - 180 с.

3. 3D-плёнка для ламинирования [Електронний ресурс] / Группа компаний «Континент» - Режим доступу : http://kontinent.info/materialy_dlja_ proizvodstva_reklamy/materialy_dlja_shirokoformatnoj_pechati/katalog/laminir juschie_plenki/3dpljonka_dlja_laminirovanija.

4. Кирилюк А. В. Дослідження ламінування листівок / А. В. Кирилюк, О. В. Зоренко // Технологія і техніка друкарства. - 2011. - № 4. - С. 46-56. - Режим доступу : http://ttdruk.vpi.kpi.ua/article/view/33487.

5. Кирилюк А. В. Технологічні особливості ламінування листівок / А. В. Кирилюк, О. В. Зоренко, Т. В. Розум // Поліграфія і видавнича справа. 2011. - № 4. - C. 90-101.

6. Воробьев Д. В. Технология послепечатных процессов / Д. В. Воробьев. - М. : МГУП, 2000. - 420 с. 
7. Левкина Н. Л. Адгезия в полимерных композиционных материалах Н. Л. Левкина. - Саратов : СГТУ, 2007. - 28 с.

8. Ламинация цифровых отпечатков с помощью пленки GMP Ultra Bond [Електронний ресурс] / GMP Санкт-Петербург. - Режим доступу : http:// gmpspb.ru/posts/post/ublamination.

9. Припресовування плівки / Ламінування // Друкуймо : Вісник поліграфії. - 2003. - № 1. - С. 20-27.

10. Широкоформатные ламинаторы [Електронний ресурс] / Компьюарт. - 2005. - № 7. - Режим доступу : http://www.compuart.ru//article/8990.

11. Здибняк М. Без складок и морщин [Електронний ресурс] / М. Здибняк // Publish. - 2008. - № 2. - C. 58-77.

12. Типичные ошибки при широкоформатном ламинировании [Електронний ресурc] / Publish. - 2004. - № 3. - Режим доступу : http://www. publish.ru/ articles/200403_4050433.

13. Laminating problems and solutions [Електронний ресурс] / MACtac. Режим доступу : http://www.mactac.it/datas/files/technical_bulletin_7.8_laminating_problems_and_solutions.08.2015pdf.pdf.

14. Советы по работе на промышленном рулонном ламинаторе [Електронний ресурс] / «СОФИС». - Режим доступу : http://lamplenka.ru/sovetpo-rulonnoy-laminacii.html.

15. Антоненко С. В. Технология тонких пленок / С. В. Антоненко. - М. : МИФИ, 2008. - 104 с.

\section{References}

1. Bobrov, V. I. \& Senatorov, L. Ju. (2008). Tehnologija i oborudovanie otdelochnyh processov [Technology and equipment for finishing processes]. Moscow: MGUP [in Russian].

2. Havenko, S. F. \& Lazarenko, E. T. \& Mamut, B. H. \& Sambulskyi, M. V. \& Tsymanek, la. \& Yakutsevych, S. \& Yarema, S. M. (2003). Ozdoblennia drukovanoi produktsii: tekhnolohiia, ustatkuvannia, materialy [Finishing of printed products: technology, equipment, materials]. Kyiv: Un-t 'Ukraina'; Lviv: Ukr akad. drukarstva [in Ukrainian].

3. 3D-pljonka dlja laminirovanija [3D film for lamination]. Retrieved from http://kontinent.info/materialy_dlja_proizvodstva_reklamy/materialy_dlja_shirokoformatnoj_pechati/katalog/laminirjuschie_plenki/3dpljonka_dlja_laminirov anija [in Russian].

4. Kyryliuk, A. V. \& Zorenko, O. V. (2011). Doslidzhennia laminuvannia lystivok [Research of laminating cards]. Journal of Tekhnolohiia i tekhnika drukarstva Technology and Technique of Typography, 4, 46-56. Retrieved from http://ttdruk.vpi.kpi.ua/article/view/33487 [in Ukrainian].

5. Kyryliuk, A. V. \& Zorenko, O. V. \& Rozum, T. V. (2011). Tekhnolohichni osoblyvosti laminuvannia lystivok [Technological features of lamination cards]. Journal of Polihrafiia i vydavnycha sprava - Printing \& publishing, 4, 90-101 [in Ukrainian].

6. Vorob'ev, D. V. (2000). Tehnologija poslepechatnyh processov [Technology of finishing processes]. Moscow: MGUP [in Russian].

7. Levkina, N. L. (2007). Adgezija v polimernyh kompozicionnyh materialah [Adhesion in polymeric composite materials]. Saratov: SGTU [in Russian].

8. Laminacija cifrovyh otpechatkov s pomoshh'ju plenki GMP Ultra Bond [Lamination of digital prints using film GMP Ultra Bon]. Retrieved from http://gmpspb.ru/posts/post/ublamination [in Russian]. 
9. (2003). Prypresovuvannia plivky / Laminuvannia [The stamping of film / Lamination]. Journal of Drukuimo: Visnyk polihrafii. — Prints: Bulletin of Printing, 1, 20-27 [in Ukrainian].

10. (2005). Shirokoformatnye laminatory [Large format laminators]. Journal of Komp'juart. - CompuArt, 7. Retrieved from http://www.compuart.ru//article/8990 [in Russian].

11. Zdibnjak, M. (2008). Bez skladok i morshhin [Without folds and wrinkles]. Journal of Publish, 2, 58-77 [in Russian].

12. (2004). Tipichnye oshibki pri shirokoformatnom laminirovanii [Typical errors in large-format lamination]. Journal of Publish, 3. Retrieved from http://www.publish.ru/ articles/200403_4050433 [in Russian].

13. Laminating problems and solutions. Retrieved from http://www.mactac.it/datas/files/technical_bulletin_7.8 _laminating_ problems_and_solutions.08.2015pdf.pdf [in English].

14. Sovety po rabote na promyshlennom rulonnom laminatore [Tips for working in an industrial web laminator]. Retrieved from http://lamplenka.ru/ sovet-po-rulonnoy-laminacii.html [in Russian].

15. Antonenko, S. V. (2008). Tehnologija tonkih plenok [Technology of thin films]. Moscow: MIFI [in Russian].

\section{Исследовано влияние параметров технологического процесса ламинирования на адгезию пленки к оттискам электрографической печати.}

\section{Ключевые слова: ламинирование; адгезия; электрографическая печать; температура и скорость ламинирования; процент наложения красок; прочность адгезии.}
The influence of the laminating process parameters on the adhesion of the film to the printed sheets is investigated.

\section{Keywords: laminating; adhesion; electrophotographic printing; temperature and speed of lamination; percentage of inks overlay; adhesive strength.}

